\title{
MAKALAH \\ SEJARAH MODERNISASI DAN PENGARUHNYA TERHADAP BERBAGAI BIDANG KEHIDUPAN MASYARAKAT
}

Diajukan untuk memenuhi tugas Mata Kuliah Sejarah Eropa

Dosen Pengampu:

Dr. Mohamad Zaenal Arifin Anis, M.Hum.

Mansyur, S.Pd., M.Hum.

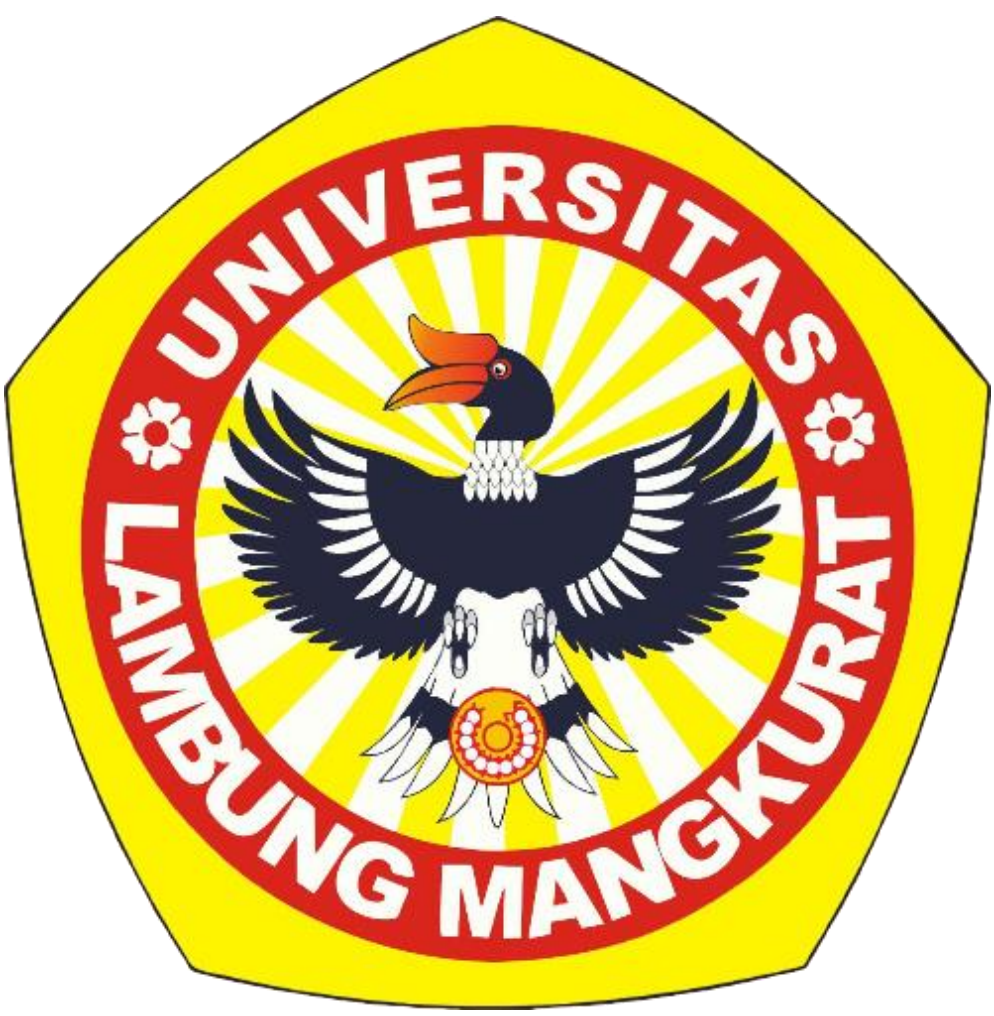

Disusun Oleh :

$$
\begin{array}{ll}
\text { Nama } & \text { : Rudi Resnawan Ansyari } \\
\text { NIM } & : 2010111110005
\end{array}
$$

A2 Pendidikan Sejarah

PROGRAM STUDI PENDIDIKAN SEJARAH

FAKULTAS KEGURUAN DAN ILMU PENDIDIKAN

UNIVERSITAS LAMBUNG MANGKURAT

BANJARMASIN

2021 


\section{KATA PENGANTAR}

Syukur Alhamdulillah senantiasa penulis panjatkan kehadirat Allah SWT yang telah melimpahkan rahmat dan karunia-Nya, sehingga penulis dapat menyelesaikan makalah ini guna memenuhi tugas Mata Kuliah Sejarah Eropa, dengan judul: "SEJARAH MODERNISASI DAN PENGARUHNYA TERHADAP BERBAGAI BIDANG KEHIDUPAN MASYARAKAT"

Makalah ini berisi tentang definisi modernisasi, sejarahnya timbulnya teori modernisasi pasca perang dunia kedua dan pengaruhnya pada berbagai bidang kehidupan masyarakat.

Mungkin makalah yang saya tulis ini masih jauh dari kata sempurna. Oleh karena itu, saya mengharap kepada para pembaca memberikan saran dan kritik yang bersifat membangun demi perbaikan ke arah sempurna. Demikian yang dapat saya sampaikan, semoga para pembaca dapat mengambil manfaat dan pelajaran dari makalah ini.

Banjarmasin, 18 Mei 2021

Penulis 


\section{DAFTAR ISI}

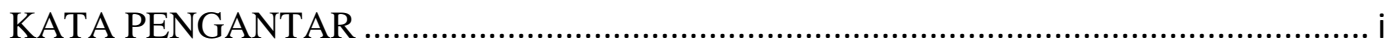

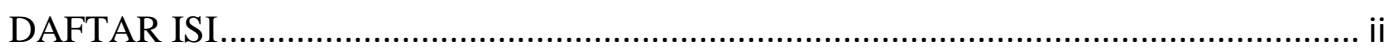

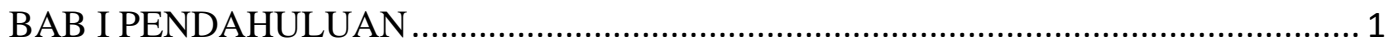

1.1. Latar Belakang Masalah.................................................................................... 1

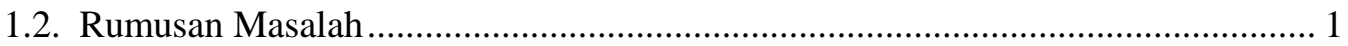

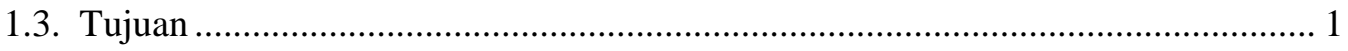

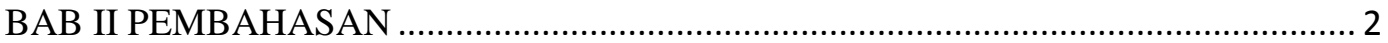

2.1. Pengertian Modernisasi ........................................................................................ 2

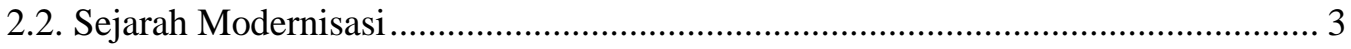

2.3. Pengaruh Modernisasi Terhadap Berbagai Bidang Kehidupan ............................... 4

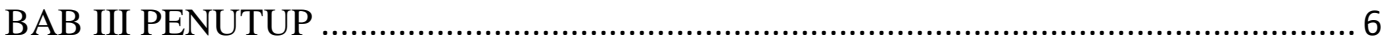

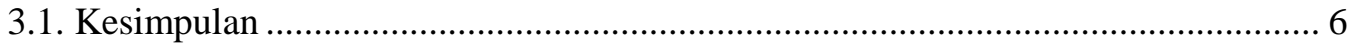

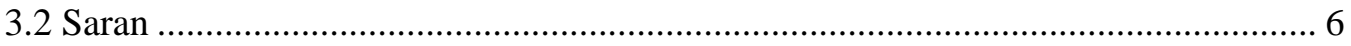

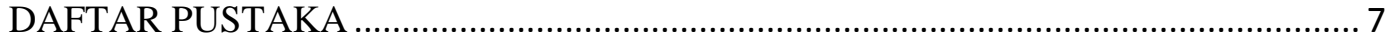




\section{BAB I PENDAHULUAN}

\subsection{Latar Belakang Masalah}

Seiring berkembangnya zaman maka pola pikir masyarakat akan berubah dan berkembang karena pada hakikatnya setiap manusia ingin merasakan hidup yang lebih mudah dan maju, maka dari itulah manusia akan selalu berinovasi pada kehidupannya sehingga membuat perubahan di kehidupan masyarakat. Perubahan tersebut semakin pesat dikarenakan ditemukannya teknologi informasi dan komunikasi yang membuat pola pikir masyarakat semakin terbuka dan berkeinginan untuk maju.

Dengan perkembangan zaman saat ini, setiap orang haruslah mengalami kemajuan pola pikir agar dapat bersaing baik dalam bidang sosial, ekonomi, politik maupun teknologi yang terus berubah seiring perkembangan zaman. Dalam perubahan tersebut, modernisasi sangatlah berpengaruh sehingga pola pikir masyarakat dapat berubah.

\subsection{Rumusan Masalah}

Rumusan masalah pada makalah ini adalah:

1. Apa pengertian dari Modernisasi?

2. Bagaimana sejarah munculnya Modernisasi pasca perang dunia kedua?

3. Bagaimana pengaruh Modernisasi terhadap kehidupan masyarakat?

\subsection{Tujuan}

Tujuan dibuatnya makalah ini adalah

1. Mengetahui Definisi dari Modernisasi

2. Untuk mengetahui sejarah munculnya Modernisasi pasca perang dunia kedua

3. Untuk mengetahui pengaruh Modernisasi terhadap kehidupan masyarakat 


\section{BAB II PEMBAHASAN}

\subsection{Pengertian Modernisasi}

Modernisasi kadang disamakan dengan westernisasi padahal keduanya adalah dua hal yang berbeda. Jika westernisasi adalah proses meniru budaya dan aspek kehidupan masyarakat barat sedangkan modernisasi dapat diartikan sebagai perubahan aspek kehidupan yang tadinya dalam keadaan masih tradisional menjadi kearah modern (Martono, 2012:80).

Modernisasi sangat erat hubungannya dengan perkembangan ke arah kemajuan. Manusia akan selalu membuat inovasi untuk mempermudah kehidupannya dan itu berdampak kepada perubahan pola pikir masyarakat yang lain. Seperti halnya masuknya teknologi informasi maka dapat dengan mudah merubah pola pikir masyarakat yang tadinya irasional menjadi rasional. Cepat atau lambat sistem masyarakat sudah dipastikan akan berubah entah itu kearah kemajuan atau malah berupa kemunduran (Rosana, 2015:76).

Globalisasi menjadi kata untuk menggambarkan masa kini, Era globalisasi memberikan dampak yang sangat besar terhadap berbagai aspek kehidupan di masyarakat. Jika dalam pandangan kebudayaan maka globalisasi dapat diartikan sebagai perubahan proses dunia untuk menjadi homogen (Anis, 2015:53). Sehingga pada era globalisasi pemikiran setiap individu haruslah mengalami modernisasi agar tercapai kehidupan yang lebih berkembang dan maju.

Modernisasi mencakup berbagai bidang yang sangatlah kompleks dan luas dan berdampak besar terhadap sejarah dan budaya karena masyarakat berkaitan erat dengan teknologi informasi yang memperkenalkan akan budaya lain yang sangat berbeda pada setiap masyarakat. 


\subsection{Sejarah Modernisasi}

Teori Modernisasi lahir setelah usainya perang dunia kedua yang dimenangkan blok sekutu dan kekalahan pada blok poros atau Axis. Amerika serikat menjadi negara adidaya yang mendominasi setelah perang dunia kedua sedangkan negara-negara di Eropa seperti Prancis dan Jerman semakin melemah setelah adanya perang dunia kedua, banyak negara yang sebelumnya di bawah kekuasaan bangsa Eropa mulai memerdekakan diri seperti negara di kawasan Afrika dan Asia. Di saat Bangsa Eropa mulai melemah Uni Soviet meluaskan pengaruhnya mulai dari Eropa Timur sampai ke kawasan Asia.

Pada masa perang dingin, dibentuklah tiga istilah klasifikasi negara di dunia yaitu:

- Dunia Pertama, meliputi negara industri yang maju seperti Amerika Serikat, Kanada dan Eropa barat hingga Jepang yang berhasil bangkit pasca perang dunia kedua.

- Dunia Kedua, meliputi masyarakat sosialis seperti Uni Soviet, Tiongkok dan Kuba.

- Dunia Ketiga, meliputi negara yang tidak memihak kubu manapun pada era perang dingin dan negara pasca kolonial yang baru merdeka dan terbelakang dalam hal industri (Rosana, 2015:72).

Negara yang baru merdeka dari jajahan bangsa Eropa mulai mencari model sistem politik untuk digunakan sebagai contoh dan Uni Soviet memanfaatkan kesempatan tersebut untuk mempengaruhi negara yang baru merdeka dengan ideologi komunisnya. Secara tidak langsung hal tersebut membuat Amerika serikat turut merasakan ancaman perang ideologi dari Uni Soviet dan membuat Amerika serikat ingin memperluas pengaruh politiknya. Amerika serikat mencari solusi dengan memberikan dorongan serta fasilitas kepada para ilmuwan bidang sosial agar memahami negara yang baru merdeka tersebut sekaligus mencari cara untuk mengatasi pengaruh ideologi yang dibawa Uni Soviet (Fakih: 2009:47). 
Teori modernisasi tidak hanya tentang gerakan akademis, Teori Modernisasi di rumuskan sebagai konteks sejarah perubahan kekuatan dalam kepemimpinan dunia setelah perang dunia ke dua yang telah didominasi oleh Amerika Serikat. Bagi teori modernisasi, ideologi yang dibawa Uni Soviet adalah ancaman terhadap pembangunan pada negara yang baru merdeka sekaligus menyatakan bahwa negara yang baru merdeka memerlukan bantuan Amerika Serikat

Teori Modernisasi muncul karena diperlukan cara dalam menghadapi masalah yang ada pasca perang dunia kedua. Dalam teori modernisasi, negara yang baru merdeka akan mengikuti jalan yang sama dengan negara barat dan berkembang melalui proses modernisasi. sehingga negara yang terkebelakang atau tertinggal dapat mengatasi masalah yang dimilikinya dan mengejar ketertinggalannya untuk berkembang ke arah yang lebih baik dan dapat hidup berdampingan dalam masyarakat global. (Rosana, 2015:71)

Modernisasi sering disalahartikan sebagai westernisasi dikarenakan secara historis keduanya sama-sama berawal sebagai gerakan dari barat dan sama sebagai proses perubahan dari sesuatu yang dianggap tertinggal menjadi sesuatu yang dianggap lebih maju. Akan tetapi dalam hal proses modernisasi lebih bersifat umum dan tidak mutlak dalam hal meniru budaya barat.

\subsection{Pengaruh Modernisasi Terhadap Berbagai Bidang Kehidupan}

Manusia akan selalu membuat inovasi untuk mempermudah kehidupannya sehingga Modernisasi dapat mencakup berbagai bidang yang sangat luas dan kontak budaya membuat proses modernisasi menjadi lebih cepat dan kompleks, modernisasi tidak hanya mempengaruhi ekonomi, politik sosial, pendidikan atau kesehatan tapi juga mempengaruhi pola pikir manusia.

- Bidang Ekonomi

Pada bidang ekonomi, modernisasi memberikan pengaruh pada masyarakat untuk mulai mengembangkan sistem perekonomiannya yang tadinya secara tradisional menjadi modern sehingga produktivitas dapat meningkat. Seperti dimasa sekarang ini kita bisa memanfaatkan teknologi 
untuk melaksanakan jual beli online dan pada sektor industri tenaga manusia mulai digantikan oleh tenaga mesin agar bisa meningkatkan produktivitas.

- Bidang politik

Pada bidang politik, modernisasi dapat dilihat pada pembentukan organisasi internasional seperti PBB dan terjalinnya kerjasama bilateral dan multilateral.

- Bidang sosial

Pada bidang sosial, modernisasi bisa dilihat dari maraknya media sosial yang digunakan untuk memudahkan komunikasi.

- Bidang pendidikan

Dengan adanya pengaruh modernisasi di bidang pendidikan maka media pembelajaran, sumber pembelajaran dan sarana prasarana yang dibutuhkan menjadi mudah diakses. Jika yang tadinya siswa harus pergi ke perpustakaan untuk mencari buku sebagai media pembelajaran, sekarang siswa dapat dengan mudah mencari media pembelajaran di internet.

- Bidang kesehatan

Dengan pengaruh modernisasi pada bidang kesehatan maka masyarakat dapat menggunakan alat yang lebih canggih dan obat yang sudah teruji penelitian sehingga masyarakat tidak perlu lagi menggunakan obat tradisional yang belum terbukti khasiatnya

- Pola pikir masyarakat

Pengaruh modernisasi terhadap pola pikir masyarakat adalah berubahnya pola pikir yang sebelumnya irasional menjadi rasional. Modernisasi juga membuat masyarakat berpikir kritis dan lebih terbuka terhadap hal baru. 


\section{BAB III PENUTUP}

\subsection{Kesimpulan}

Modernisasi merupakan proses perubahan aspek kehidupan yang tadinya dalam keadaan masih tradisional menjadi modern. Modernisasi sering disalahartikan sebagai westernisasi dikarenakan secara historis keduanya samasama berawal sebagai gerakan dari barat dan sama sebagai proses perubahan dari sesuatu yang dianggap tertinggal menjadi sesuatu yang dianggap lebih maju. Akan tetapi dalam hal proses modernisasi tidak mutlak dalam hal meniru budaya barat.

Sejarah lahirnya Teori Modernisasi diawali munculnya Amerika serikat yang menjadi negara adidaya dan mendominasi setelah perang dunia kedua serta perang ideologi dengan Uni Soviet untuk mempengaruhi negara yang baru merdeka. Teori Modernisasi muncul sebagai solusi dalam menghadapi masalah yang ada pasca perang dunia kedua.

Manusia akan selalu membuat inovasi untuk mempermudah kehidupannya sehingga Modernisasi dapat mencakup berbagai bidang yang sangat luas dan kontak budaya membuat proses modernisasi menjadi lebih cepat dan kompleks, modernisasi tidak hanya mempengaruhi ekonomi, politik sosial, pendidikan atau kesehatan tapi juga mempengaruhi bagaimana pola pikir manusia yang sebelumnya irasional menjadi rasional. Modernisasi juga membuat masyarakat berpikir kritis dan lebih terbuka dengan hal yang baru.

\subsection{Saran}

Seiring perkembangan zaman arus modernisasi dan globalisasi akan terus terjadi. Oleh sebab itu, kita haruslah mengalami kemajuan pola pikir agar dapat bersaing baik dalam bidang sosial, ekonomi, politik maupun teknologi yang terus berubah seiring perkembangan zaman. 


\section{DAFTAR PUSTAKA}

Anis, M. Z. A. (2015). Sejarah Bukan Warisan Melainkan Pembelajaran

Anis, M. Z.A.(2016). Sejarah, Kesadaran Sejarah dan Pupusnya Identitas Nasional

Fakih, Mansour .(2009). Runtuhnya Teori Pembangunan dan Globalisasi, Yokyakarta: INSISTPress.

Martono, N. (2012). Sosiologi Perubahan Sosial: Perspektif Klasik, Modern, Posmodern, Dan Poskolonial. Jakarta: PT Rajagrafindo Persada

Rosana, E. (2015). Modernisasi dalam Perspektif Perubahan Sosial. Al-Adyan: Jurnal Studi Lintas Agama, 10(1), 67-82. 